\title{
Dream time and anti-imperialism in the writings of Olive Schreiner
}

\author{
Jade Munslow Ong*
}

University of Salford, UK

\begin{abstract}
This article explores how Olive Schreiner utilizes politicized modernist aesthetics, specifically the manipulation of time through allegory and dream, to resist structures of empire. The claim that Schreiner's work should be received and analysed as modernist builds on recent work in global modernist studies that views modernisms as multiple, and occurring across various temporalities and geographies, whilst responding to the drive in postcolonial studies to reshape modernism with an awareness of empire. Analysis of the repetitive dream cycles within and across Schreiner's texts reveals how she disrupts the conventional chronologies and associated ideologies introduced by colonizers in South Africa in ways that can be interpreted as modernist. Beginning with close readings of the opening scenes in the novels Undine: A Queer Little Child (written 1870s) and The Story of an African Farm (1883), the article then considers the role of alternative temporalities associated with dreams in the short allegory "Three Dreams in a Desert" (1887), to suggest that Schreiner's "dream time" offers a form of postcolonial resistance to the imposed "imperial clock time" of life under colonial rule.
\end{abstract}

Keywords: Olive Schreiner, time, modernism, dream, allegory, postcolonial

\footnotetext{
*Email: J.MunslowOng@ salford.ac.uk
} 


\section{Introduction}

It may seem surprising to consider the writings of Olive Schreiner (1855-1920) in the context of an investigation into intersections of modernism and postcolonialism. Her literary outputs are more commonly included in analyses of Victorian, New Women or colonial writers, as she began writing all three of her novels, and various allegories, whilst living in South Africa in the 1870s, and the texts examined in this article were published or abandoned by 1887 (when she returned to South Africa after eight years in England). ${ }^{1}$ Time-bound and centreperiphery models used to identify literary movements would position Schreiner outside of the times and/or spaces traditionally associated with modernist and postcolonial literatures and cultures. ${ }^{2}$ Despite this, I argue that attempting to read Schreiner's work in ways that privilege dominant Victorian literary modes, in particular realism, cannot fully account for the ways that her texts break with tradition in terms of form and argument. This approach is informed by Adam Barrows's suggestion that the "dominant aesthetic tendency of modernism" to experiment "with the representation of human temporality in ways that would radically alter prevailing aesthetic forms" is linked to the processes of imperialism $(2011,2)$.

That Schreiner's writings should be interpreted in line with modernist innovation becomes evident in the opening pages of Undine: A Queer Little Child (1929) and The Story of An African Farm (1883), and in the allegory, "Three Dreams in a Desert" (1887), all of which use non-realist forms to explore alternative temporal experiences as a way of critiquing empire. David Leon Higdon describes time in realist novels by authors such as Walter Scott, Jane Austen and George Eliot as "process time", linear chronology that "continually unfolds and encourages development through successive stages culminating in a specific result. Time thus stresses a process and its underlying causality" (1977, 4). Methods of interpreting Schreiner's work that privilege this model serve to diminish the political and aesthetic achievements of her writings, and yet Schreiner scholarship has been dominated by attempts 
to read her novels in these, or similar, terms. The need to prise Schreiner's writings "loose from the conventions of the realist Victorian novel" as they will always provide a "failed example of this [form]", is highlighted by Liz Stanley, who refers to Undine as an "experimental and non-realist novel conceived on structural lines" that needs "rethinking with this in mind" $(2002,59)$. Stanley does not attempt this type of analysis herself, and so this article responds to her call by arguing that Schreiner's texts experiment with time in ways that can be interpreted as modernist, particularly as they counter linear, chronological and causal patterns that in Victorian culture were regulated by the clock, and used to shape the realist novel.

All of Schreiner's literary works show evidence of her attempts to find narrative forms that could more accurately represent her anti-imperialist politics than the triple-decker novel structure dominant in the Victorian period. On 29 June 1896 Schreiner wrote to her friend, the prominent Cape liberal, John X. Merriman, that: "strange as it may seem I have a most peculiar antipathy to novels" (Olive Schreiner Letters Online). This is reflected in the fragmented forms of both Undine and African Farm, neither of which conform to the realist mode, as well as in Schreiner's preference for the allegorical short story, which she uses to emphasize the intensity of feeling, introspection, encounters, flexibility and open endings, that the traditional marriage or death plot novel could not always encompass. In an earlier letter, from February 1888, this time to the editor Ernst Rhys, Schreiner wrote: "Sometimes I find by throwing a thing into the form of an allegory I can condense four or six pages into one, with no loss but a great gain to clearness" (Olive Schreiner Letters Online). For Schreiner, this clarity might be productively thought of as the ability to express radical politics at the level of content and form.

Since the publication of Fredric Jameson's “Modernism and Imperialism” (1990), consideration of the significance of empire in the context of modernism has gained 
momentum (Booth and Rigby 2000; Childs 2007; Patke 2013), and fed into concepts of "global modernisms" outside of early-20th-century Euro-American locations (Stanford Friedman 2006; Doyle and Winkiel 2005; Wollaeger and Eatough 2012). In line with arguments made by these scholars and others, this article challenges temporally- and geographically-bound views of modernism by offering a case study on Schreiner, whose literature does not fit into genealogies of development hitherto mapped by scholars of European, or even African, modernisms. Although Tim Woods's chapter in the Oxford Handbook of Modernisms works to legitimize and validate forms of African modernism, his analysis reveals a commitment to the view that African modernisms could only occur after, and as a result of, European innovation (Woods 2010, 926-941). Thus European engagement with African forms is seen as an adoption of the "primitive", and African modernisms are deemed to come after Euro-American incarnations. This sense of belatedness and causality pervades scholarly work in this area, as the editors of the Oxford Handbook of Modernisms show:

It is not just that modernism is influenced by "other" cultures - a view that does little to destabilise the centre-margin binary - but that it is completely overhauled by writers and artists who re-create and re-deploy modernism in their own culturally specific terms and for their own distinctive purposes. (Brooker et al. 2010, 12)

Whilst this assertion performs important work in terms of recognizing the radical potential of modernisms from outside of Western Europe and the USA, it does not account for an antidevelopmental narrative that challenges the primary status of the west.

A reading of Schreiner as a modernist writer calls into question what constitutes modernist practice. Although dreams have been an object of study within modernist and 
postcolonial scholarship, and allegory has prevailed as a dominant mode in colonial and postcolonial writing, the connection between modernism and allegory may not seem so obvious. Only recently has Rajeev Patke made the case for considering the relationship between the two in the context of an investigation into correlations and continuities between modernist and postcolonial literatures $(2013,108-112)$. In line with more traditional approaches, however, Jameson appears to read modernism and allegory as separate:

If allegory has once again become somehow congenial for us today, as over against the massive and monumental unifications of an older modernist symbolism or even realism itself, it is because the allegorical spirit is profoundly discontinuous, a matter of breaks and heterogeneities, of the multiple polysemia of the dream rather than the homogenous representation of the symbol. $(1986,73)$

The association of modernism with the totalizing effects of the symbol, and allegory with splintered dream, may appear problematic for a consideration of Schreiner's allegorical writings as modernist. However, in "Modernism and Imperialism", Jameson famously suggests that modernist literature is marked by the "spatial disjunction" of life in the metropolis with life in the colonies and that "as artistic content it will now henceforth always have something missing about it" $(1990,51)$. Re-reading Jameson's dream-allegory alongside this account of the impact of empire on modernist literature reveals that both are described as fragmented. It is this fragmentary nature of dream-allegory that enables Schreiner to respond to and challenge the structures of empire, in ways that move beyond the conventions of linear, teleological, realist texts. 


\section{Imperial clock time}

The title of this section is informed by the work of historian Giordano Nanni, who has recently explored the relationship between empire and time. He explains that:

Time is a dimension through which the fundamental tenets of a culture are learnt, disseminated and held to be true. As such it provided one of the key standards of knowledge and models of behaviour against which Europeans sought to reform their

Others in the colonies - operating simultaneously as a category for establishing the cultural and racial inferiority of local populations and as a channel for reforming the latter into so-called modern, civilised and Christian subjects. $(2012,13)$

Nanni illustrates how the processes of colonization involve concomitance between the introduction of western methods for telling the time, the spread of Christianity through missionaries, and the organization of labour and worship. "Imperial clock time" then, is a phrase I use to refer to the limitations and associated ideologies imposed by structures such as the seven-day week and chronological methods for telling the time in the colonies. Counter to this, the non-linear manipulations of time through allegory and dream that occur in Schreiner's writings can be seen to challenge the principles and behaviours determined by the colonial powers in South Africa.

The ticking clock scenes in African Farm, and to a lesser extent, Undine, have provided focal points for scholars keen to uncover the meanings generated by the experimental temporalities of Schreiner's work. In Joyce Avrech Berkman's reading of African Farm, the clock evokes "the terror of God's judgement" (1989, 48); Anne McClintock suggests it is "a grotesque fetish of Victorian industrial progress" $(1995,278)$; Gerald Monsman considers that "the deadly divinity of moon-as-watch emphasizes human 
defects and damns humanity for them" $(1991,55)$; whilst for Patricia Murphy, the watch is "associated with patriarchal heritage" (2001, 196). These readings illuminate the freethinking, socialist and feminist aspects of Schreiner's radicalism. What they do not fully account for, however, is how the antipathy towards European methods for structuring and organizing time shown in Schreiner's writings, can also be interpreted as specifically antiimperialist.

Temporal and spatial concerns are united in the opening line of African Farm as "The full African moon poured down its light from the blue sky into the wide, lonely plain" (Schreiner 1998, 1). The moon, as marker of time, is associated with the land through light. This conflation expresses anti-colonial impulses, because where Nanni notes that western calendars and clocks sought to imitate patterns indicated by the sun $(2012,50)$, Keletso Atkins reveals that in the nineteenth century, native African methods for telling the time often relied on the moon $(1993,80-83)$. The suggestion here then, is that temporality in the novel does not adhere to "imperial clock time", but rather appears as what I call "dream time", an aesthetically and politically progressive non-linear allegorical mode that works to undermine colonial control. Although the landscape revealed by the bright moon is a fairly realistic depiction of the semi-desert karroo regions of South Africa, it also has deeper allegorical meanings expressed through its chronotopic significance. A sense of limitation is created by the underdeveloped and dusty "dry, sandy earth, with its coating of stunted 'karroo' bushes a few inches high, the low hills that skirted the plain" (Schreiner 1998, 1). The Victorian ideal of history as progress cannot find a place here, where the arid surroundings are marked by struggle and decline, and so this description presents a view of history disassociated from the realist mode, in which time is neither chronological, nor developmentally progressive. 
Time is allegorized as space in African Farm, as the "solemn monotony of the plain" referred to in the opening line of the second paragraph introduces the idea of a tedious, unvaried temporal experience, which is "broken" by a man-made imposition on the landscape: "a heap of round ironstones piled one upon the other, as over some giant's grave" $(1998,1)$. Death causes disruption and fragmentation, and is presented on a grand scale here, so that the "giant's grave" overlooks the roofs of the farm outbuildings that show "every rib in the metal" (1). These images can be viewed in light of Walter Benjamin's key contentions that "in allegory the observer is confronted with the facies hippocratica [death's head] of history as a petrified, primordial landscape" and that "allegories are, in the realm of thoughts, what ruins are in the realm of things" $(2003,166,178) .{ }^{3}$ Schreiner and Benjamin share an investment in undermining accounts of history as a continuum of progress that culminates in religious salvation. However, where for Benjamin, in this early study at least, allegory has limited political utility, for Schreiner, the skeletal buildings and grave of stones provide images of decay and interrupted experiences of time that hint at a discarded past with the potential to reveal a perspective other than that of the ruling colonial powers. The interactions between nature and human experience are further shown in the similarities between the colonial homestead's "bare red walls", and the garden, which is "a bare patch of sand and two straggling sunflowers" (Schreiner 1998, 1). Taken together, the karroo and the deteriorating homestead comprise a chronotope of time as space, where the emptiness or "bareness" of the objects that should have been symbols of colonial power and authority, forms an allegory of the effects of colonization on experiences of time. The fragments of the past that litter Schreiner's allegorized landscape interrogate the imperialist narratives of progress that work to erase the violence of colonization from cultural memory.

Schreiner presents death in nature to counter narratives of progressive human history used in Victorian imperialist, evolutionary, industrial and religious rhetoric, as well as to 
challenge any view of human experience as unaffected by natural processes. For Benjamin, allegory is "at home in the Fall" $(2003,234)$, with the potential to disrupt and analyse the seeming coherence of the temporal experiences associated with modernity. Death marks a shift here, rather than a final cessation. This conception of allegory draws attention to historical acts, and, in Schreiner's novel, enables her to demonstrate the ways that imperialism attempts, and fails, to distance natural processes from human experience - such as in the use of mechanical clocks that approximate the sun's time to regulate colonial labour (Nanni 2012, 50). Schreiner's postcolonial impetus is shown through metaphorically significant shades of light and dark as the glimmers of brightness in the night-time setting suggest genuine hope. So the African moon fills the sky with a "white light" and "quite peculiar brightness"; "a clump of prickly-pears lifted their thorny arms, and reflected, as from mirrors, the moonlight on their broad, fleshy leaves"; and the rib-like roofs are "burnished silver" (1998, 1). Past, present and future coincide here as the potential for alternative experiences of time and escape from the limitations of colonial life, are shown through the brightness of the landscape and the upwards-reaching plants. Schreiner displays death and struggle through allegory to break apart western accounts of history, working through the concerns of the present as a way of reaching towards alternative, postcolonial futures.

The similarities between Undine, Schreiner's first novel, and African Farm, are immediately obvious, as the opening lines of Undine describe the "cold white light of an almost full moon" $(1972,2)$ shining down on a landscape of "red sand, great mounds of stones, and bushes $[\ldots]$ an old Dutch farmhouse built of the brightest red brick to match the ground and stones; an old stone wall broken down here and there at irregular intervals" (1). In both novels, the child protagonists, Lyndall and Waldo in African Farm, and the titular protagonist in Undine, are awake in these night-time settings, where the potential offered by the alternative temporality of the chronotopic landscapes is accessible to two of the three 
characters. Lyndall is open to different ways of being and thinking, signified by the way she stretches her limbs out in bed and "looked at the moonlight that was bathing them" $(1998,2)$. Undine too, sits outside in the light of the moon, "busy cogitating" $(1972,2)$. Waldo, however, lies petrified in the dark, "door and shutter were closed, not a ray of light entered anywhere" $(1998,2)$, listening to sound of a ticking clock. He is trapped in a waking nightmare within the colonial homestead, without access to the dreamlike scenery outdoors.

The repetition within and across Schreiner's writings illustrates how chronological accounts of time are associated with imperialist principles, and the clock scenes in both novels are worth quoting at length. In African Farm, Waldo hears the sound of his father's hunting watch:

Tick-tick-tick-tick! One, two, three, four! He lost count presently, and only listened. Tick-tick-tick-tick!

It never waited; it went on inexorably; and every time it ticked a man died! He raised himself a little on his elbow and listened. He wished it would leave off.

$[\ldots]$

"Dying, dying, dying!" said the watch; "dying, dying, dying!"

He thought of the words his father had read that evening - "For wide is the gate and broad is the way, that leadeth to destruction, and many there be which go in thereat."

"Many, many, many!" said the watch.

\section{$[\ldots]$}

The boy lay with his eyes wide open. He saw before him a long stream of people, a great dark multitude that moved in one direction; then they came to the dark edge of the world, and went over. 
$[\ldots]$

And the watch said, "Eternity, eternity, eternity!"

"Stop them! Stop them!” cried the child.

And all the while the watch kept ticking on; just like God's will, that never changes or alters, you may do what you please. (1998, 3-4)

In Undine, the protagonist is told to stop come inside for prayers. Here, the clock drowns out all other thoughts:

"Another week gone, another day gone. What have you done? We never come back, we moments; we fly, but we never return, never, never, tick, tick. What have you done with us? If you do the best you can with all the rest of us, you can never bring one of us back, never, never, tick, tick."

Undine tried to listen to the prayer, but the old clock's voice was louder.

"Tick, tick," cried the inexorable old clock, "what good have you ever done? How are you better able to die now than you were last week? You are nearer death, but are you ready, ready, ready, tick, tick, tick?”

Undine tried to listen to the prayer again, and she caught these words: "Thousands, O Lord, are going to destruction every moment"

"Yes, yes, yes," said the clock, "tick, tick, hell, hell, going, going, thousands, thousands, thousands, tick, tick, tick, tick.” $(1972,4-5)$

Both Undine and Waldo associate the ticking clock with men and women going to hell as each of the linear, regular beats of the clock signals a perpetual forward motion in which nothing passed is retrievable. If, as Nanni suggests, the clock and the concept of the seven- 
day week helped to organize labour and religious practices, as well as foster a sense of connectedness between the colonies and the metropolis, then the ticking watch in Schreiner's novels illustrates the demand and strain to remain "civilized", "modern", and perpetually God- and time-aware. Enforced prayer time is conflated with the ticking clock, which delivers the same message of impending doom in both texts. The repeated "tick", which does not end with the first novel, but continues across the second, further emphasizes the march to inevitable death. These passages reveal that the history of man (measured by the clock), corresponds to natural times (measured by the moon), in that death occurs in both. Where the deaths marked by the colonial prayer-clock are oppressive and never-ending, however, the deaths marked by the moon offer greater potential for the future as the moon renews each month. Unlike in the vast farmland, where time is non-linear and regenerative, time and space in the small house are bound, governed by chronological, human methods, and the inhabitants are guided by faith in a Christian God.

The terror instilled in Schreiner's young protagonists by the ordering of time is decidedly modernist in character, though unusually, their horror stems from its association with imperial control. Peter Childs suggests that "for many modernists, it is the clock, which regulates and parcels out time, that is to blame for the tyranny of space over the psychological flow of time in the mind" $(2000,59)$. For example, in A Portrait of the Artist as a Young Man, James Joyce uses the sound of ticking to offer a vision of hell as it "went on unceasingly; and it seemed to this saint that the sound of the ticking was the ceaseless repetition of the words - ever, never; ever, never" (1973, 113); and D.H. Lawrence uses a ticking clock to create Gudrun's sense of imprisonment in Women in Love, as she is "confronted by the terrible clock, with its eternal tick-tack. All life, all life resolved itself into this: tick-tack, tick-tack, tick-tack; then the striking of the hour; then the tick-tack, tick-tack, and the twitching of the clock-fingers" $(1987,464)$. Whilst work remains to be done on 
Schreiner's influence on later modernist writers, these examples show correlation between Schreiner's writings and high modernist texts. Unlike these writers however, the fear instilled by the ticking clock in Schreiner's works expresses a more particular anti-colonial impulse. Waldo and Undine's reactions to the clock specifically indicate the oppressive nature of the routines of religious worship and labour in the colonies.

Undine provides a further critique of western methods for telling the time and associated colonial ordering of human experience by illustrating the radical potential of allegory. Nanni points out that the seven-day week "silently affirms and reactualises the underlying master narrative of Judeo-Christian mythology", as God made the world in six days and rested on the seventh $(2012,6)$. For this reason, it becomes a source of terror for Undine, who believes that it would be wicked to read anything other than the Bible on a Sunday, and "one of the crimes which always came back to haunt her in the dark watchful hours of the night was her having read, on one never-to-be-forgotten Sunday afternoon, a part of that story of "The Mermaid and the Prince"" $(1972,20) .{ }^{4}$ The intertextual presence of an older allegorical form, the fairytale, which replaces the Bible (also allegorical, but in the context of missionary education read monologically), makes the important connection between alternative forms of writing and reading with anti-colonial rebellion. Both the reading of allegorical narrative forms and the use of allegory in the novel itself are associated with deviation from behaviours aligned to particular religious codes.

Throughout much of Undine and African Farm, the young characters strain against the limitations of life in colonial South Africa. Both of the New Woman characters, Undine and Lyndall, are betrayed by men, and dead by the end of the novels, though Waldo's story is slightly different. As Deborah Shapple Spillman (2012) has noted, Waldo is spiritually connected to the indigenous San who were forced out of the Eastern Cape, so his struggles act as an allegory of the effects of colonization on the native peoples. In this context, the 
death-tolling clock takes on a broader significance, as the deaths marked include those of the native people killed by the modern technologies of the colonizers. Over the course of the novel, Waldo rejects Christianity; endures the death of his father; receives a brutal whipping at the hands of the English trickster Bonaparte Blenkins; and finally is shattered by the loss of his soulmate, Lyndall. At the end, Waldo lies sleeping or dying, though this is a little more ambiguous than the deaths of the female characters. When Em, Lyndall's cousin and Waldo's childhood playmate, brings a drink of milk to Waldo, she places it down by his side so as not to disturb him:

The mother-hen was at work still among the stones, but the chickens had climbed about him and were perching on him.

\section{$[\ldots]$}

Em did not drive them away; but she covered the glass softly at his side. "He will wake soon," she said, "and be glad of it."

But the chickens were wiser. $(1998,270)$

In these closing lines of African Farm, Waldo finds comfort in his spiritual affinity for the natural world. This tendency to animism, illustrated so clearly earlier in the novel when Waldo asks "Lyndall, has it never seemed to you that the stones were talking to you?" (15), is a further expression of Waldo's relinquishing of imperialist Christianity. Here, Schreiner suggests the need to turn to alternative forms of knowledge derived from nature, rather than imperialist methods for organizing religion, labour and other human experience, in order to move beyond the limitations of colonial life. Waldo sits, resting against the wall of the waggon-house with his eyes closed, dreaming or dying. The significance of this blurring resonates throughout Schreiner's oeuvre. For Schreiner, both dreams and death cause rupture 
and fragmentation as these states of being (or non-being) are outside of the parameters of colonial control. In this ending, Waldo's death-dreaming signals a change that interrupts chronological modes of organization, and suggests future potential for postcoloniality. ${ }^{5}$ With this in mind, I turn now to a discussion of a short allegory by Schreiner to explore some of the ways that her experiments with temporality can be read as postcolonial.

\section{Dream time}

In literature as in other art forms, dreams have long been used as method for time-travel, whether that be to visit past lives, revive memories, or to communicate visions of the future, warnings and portents. For Schreiner, the temporal flexibility offered by the dream facilitates its utility as an important source and site for theorizing empire. In her work, what I call "dream time" cannot be measured by "imperial clock time", and so metaphors of sleep enable explorations of the relationships between the potential worlds inhabited by dreams and the possibility of awakening to alternative futures. Schreiner described nearly all of her allegories as dreams, and she published them fairly widely in periodicals such as the Women's Penny Paper, Fortnightly Review, and Oscar Wilde's The Woman's World. Many of these texts also feature in letters to friends, and in the published collections Dreams (1890), Dream Life and Real Life (1893), and Stories, Dreams and Allegories (1923). Schreiner also published an allegorical novella, Trooper Peter Halket of Mashonaland (1897), which explicitly attacked Cecil Rhodes's expansionism and imperialism. The focus here however, is on "Three Dreams in a Desert", an allegory that rejects teleological accounts of history and western methods for organizing temporality by using dream to blur past, present and future, time and space.

Awareness of the radical future potential of the dream was not unique to Schreiner, of course. Dreams were discussed and examined by her circle, including her lifelong friend, 
sexologist and social reformer, Havelock Ellis. In his 1911 study, The World of Dreams, he describes a moment

When we have half awakened from a dream and are just able to realize that it was a dream, that dream constantly tends to appear in a more plausible or probable light than is possible a few moments later when we are fully awake. $(1922,233)$

For both Ellis and Schreiner, the dream becomes a way to pursue change, though unlike in Ellis's study, which emphasizes the science and history of dreaming, Schreiner's understanding of dream blurs literary form, psychological experience and radical argument in ways analogous to allegory. This is explained in a letter to Ellis, dated 2 November 1888 , when she describes her understanding of allegory as poetry:

I have come to the conclusion that only poetry is truth. [ ... As soon as there is the form and the spirit, the passion and the thought, then there is poetry, or the living reality. I don't mean that I attain to true poetry - all I mean is that what makes a man strive after and seek to see the thing in that way is that it is the reality. It's the other that's fancy and fiction, and this that is real. (Olive Schreiner Letters Online)

The notion that the more complex, open-ended form of allegory, which allows for multiplicity of meanings, is in some sense truer to life, and able to convey radical ideas in clearer ways, underpins all of Schreiner's work. She argues here for the use of literary forms that do not close off meaning, but invite interpretation and express alternative potential "realities". 
Schreiner's preference for using non-realist dream-allegory can be explained by the challenge that the dream poses to traditional conceptions of history, and its flexibility in allowing for explorations of radically different futures. This view of Schreiner's allegories is supported by Claire Gill's recent essay on the publication history of Dreams, in which she notes that Schreiner's collection “anticipates modernism's self-conscious, formal departure from realist modes of narration by transcending the conventional boundaries of space and time" (2012, 317-318). Gill's reading is astute, though it does betray a commitment to timebound conceptions of modernism that this article refutes. In this context, the work of Benjamin may again be called upon given that Natalya Lusty and Helen Groth have recently noted that his conception of the dream "brings into view the dialectical relationship between sleeping and waking $[\ldots]$ as central to understanding the social and cultural processes of history" $(2013,2)$.

“Three Dreams in a Desert" opens with a traveller moving across an African plain in the heat of the day. He stops to find some respite from the oppressive sun and falls asleep. His first dream is of the mother of mankind lying prostrate in a desert. She is unable to move, as "the Age-of-dominion-of-muscular-force found her, and when she stooped low to give suck to her young, and her back was broad, he put his burden of subjection on to it, and tied it on with the broad band of Inevitable Necessity" (Schreiner 1894, 70). Whilst more obviously an allegory about female emancipation, the multiple meanings generated by the form enable an interpretation of the text as anti-imperialist too. Thus the "Age" and desert location allegorize the colonization of Africa, and the band, the ideological imperatives designed to keep both woman and African in submission. The "Age-of-nervous-force" arrives, and stabs and kills the "Age-of-muscular-force", cutting "the band that bound the burden to her back" (71). This can be read in light of Benjamin's essay on dreams and modernist surrealism, where he writes that "“Dreaming has a share in history. [ ... ] Dreams have started wars, and 
wars, from the very earliest times, have determined the propriety and impropriety - indeed, the range - of dreams" (1999b, 3). The violence that occurs in Schreiner's text radically alters conventions and changes standards of behaviour. The knife used to free the woman is a product of "Mechanical Invention", a new technology that comes with colonialism, and which enacts a more confronting violence than the death-knelling mechanical clocks of Undine and African Farm. The "Age-of-Nervous-force" does not help the woman to rise, as "He cannot help her: she must help herself. Let her struggle until she is strong" $(1894,73)$. The onus here is on the colonizer to implement the initial freedom of Africans and women, though the allegory suggests that subsequent forms of external intervention will not help in the establishment of a postcolonial world. The dream concludes as "slowly the creature staggered on to its knees" (75). This strategic de-humanizing of the woman at the end may appear negative, though, remaining cognizant of Schreiner's emphasis on the environment as a site and source for change in African Farm, this shift from "woman" to "creature" suggests a reimagining of new forms of womanhood, more attuned to nature, that may emerge through postcolonialism.

The action of the narrative indicates that tools of modernity will enable the emancipation of woman and African, and this is echoed in the form, as Schreiner uses allegorical structures associated with sustaining dominant culture, including the Bible and Bunyan's The Pilgrim's Progress (1678), in order to forward politically progressive arguments. This "writing back" at the level of form using the tools of imperialist knowledge, namely Schreiner's religious education under her missionary parents, is evident in the religious imagery used in the second of the three dreams, including in the allegorical device of personification, no doubt inspired by Bunyan. In the second of the three dreams, the traveller imagines a woman seeking the "Land of Freedom" $(1894,76)$. Reason tells her the only way is across the water of Suffering, so the woman has to abandon her man-child, and 
shake off her "mantle of Ancient-received-opinions" and "shoes of dependence" (78). Reason then asks her:

"Have you seen the locusts how they cross a stream? First one comes down to the water-edge, and is swept away, and then another comes and then another, and then another, and at last with their bodies piled up a bridge is built and the rest pass over."

The idea of self-sacrifice as necessary for human development does not draw inspiration from modes of progress governed by human culture, but through learning from nature. Schreiner dreams a location outside of a narrowly conceived view of teleological history in order to reconceive the present. This intertwining of natural life and structures with the history of mankind that was present in the chronotopic landscapes of African Farm and Undine, now becomes a method through which to achieve postcoloniality. Schreiner advocates collaboration, self-sacrifice and unity between humans as well as the natural world in order to dream the "Land of Freedom".

In the final of the three dreams, the traveller imagines himself in a land, where "on the hills walked brave women and brave men, hand in hand", and when the traveller asks where he is, he is told: "IN THE FUTURE" (84). This final dream can be read in dialogue with one of the many disparate texts collected in Benjamin's Arcades Project, the Paris exposé of 1935, in which he writes that: "Every epoch, in fact, not only dreams the one to follow, but, in dreaming, precipitates its awakening" $(1999 \mathrm{a}, 13)$. When the dream ends, the traveller wakes as "the sun passed down behind the hills; but I knew that the next day he would arise again" (85). The rising of a new sun the following day to mark the start of a period no longer 
characterized by suffering, oppression and inequality, as life under colonial rule is, suggests that Schreiner's future postcolonial world will be in harmony with natural cycles.

"Imperial clock time", as a tool of colonial control that also informs the structure of realist narratives, is resisted in Schreiner's writings. At the level of both argument and form anti-imperialism and the fragmented "dream time" of allegory - the three early examples of Schreiner's work examined in this article can be seen to challenge dominant culture. Through allegory, Schreiner dismantles simplistic causal accounts of historical events and master narratives of progress so prominent in various strands of Victorian thinking in order to reveal them as imperialist strategies. Her antipathy towards realist novel forms stemmed from the view that they are insufficiently flexible and unable to convey the full scope of her radicalism. This indicates that new methodologies, disassociated from realism, are required to interpret Schreiner's complex and challenging texts, whilst the act of analysing Schreiner as a modernist or postcolonialist itself proposes an anti-developmental narrative that revises the chronologies and geographies that have long governed our understanding of both movements. In dreaming the epochs that follow, or rather, by showing that epochs contain within them fragments of the past and thoughts of the future, Schreiner's texts provide admittedly problematic, but nevertheless important, examples of formal experimentation and anticolonial politics that predate traditional definitions of the categories of literature and culture labelled modernism and postcolonialism.

\section{Notes}

\footnotetext{
${ }^{1}$ Olive Schreiner began writing Undine: A Queer Little Child in 1873 and likely abandoned the text some time before 1877. She never intended to publish the novel, and it remained incomplete at the time of her death in 1920. It is possible that her husband, Samuel Cron Cronwright-Schreiner, modified the manuscript in now unknown ways, before publishing it
} 
in 1929. The Story of An African Farm was also written in the 1870s. Schreiner took the manuscript with her to England in 1881, where it was published in 1883. "Three Dreams in a Desert" was first published in 1887, and reprinted in the collection Dreams (1890).

2 Anna Snaith $(2014,36-66)$ provides a welcome recent attempt to consider the anticolonialism of Schreiner's final novel, From Man to Man (1926), in a modernist context.

${ }^{3}$ It is significant to note that Schreiner once told her husband that she intended to write "The Hunter" (the central allegory that appears in African Farm) "on the bones of a sheep's head" (1973, 147). A slightly edited version of “The Hunter" was later reprinted in Dreams (1890).

${ }^{4}$ Schreiner's Undine shares her name with an Ancient Greek water nymph, and an "undine" is another term for a water elf or spirit, closely associated with the mermaid.

${ }^{5}$ The term "postcoloniality" is used here because it retains "resistant pressure and agency" and recognizes the complexity of "interminglings of structural forces with local, personal experience" (Young 2001, 57).

\section{Notes on Contributor}

Jade Munslow Ong is Lecturer in Nineteenth-Century Literature at the University of Salford. She gained a PhD from the University of Manchester in February 2013 for a thesis on Olive Schreiner and primitivism.

\section{References}

Atkins, Keletso. 1993. The Moon is Dead! Give Us Our Money! The Cultural Origins of an African Work Ethic, Natal, South Africa, 1843-1900. Portsmouth, NH: Heinemann.

Barrows, Adam. 2011. The Cosmic Time of Empire: Modern Britain and World Literature. Berkeley and Los Angeles, CA: University of California Press. 
Benjamin, Walter. 1999a. The Arcades Project, translated by Howard Eiland and Kevin McLaughlin, edited by Rolf Tiedemann. Cambridge, MA and London: Belknap Press. Benjamin, Walter. 1999b. "Dream Kitsch: Gloss on Surrealism.” In Selected Writings: 19271934, edited by Michael Jennings, 3-6. Cambridge, MA: Belknap Press.

Benjamin, Walter. 2003. The Origin of German Tragic Drama, translated by John Osborne, 159-235. London: Verso.

Berkman, Joyce Avrech. 1989. The Healing Imagination of Olive Schreiner: Beyond South African Colonialism. Amherst, MA: University of Massachusetts Press.

Booth, Howard J. and Nigel Rigby. 2000. Modernism and Empire. Manchester: Manchester University Press.

Brooker, Peter, Andrzej Gasiorek, Deborah Longworth and Andrew Thacker. 2010. The Oxford Handbook of Modernisms. Oxford: Oxford University Press.

Childs, Peter. 2000. Modernism. London: Routledge.

Childs, Peter. 2007. Modernism and the Post-Colonial: Literature and Empire 1885-1930. London: Continuum.

Cronwright-Schreiner, Samuel Cron. 1973. The Life of Olive Schreiner. New York: Haskell House Publishers.

Doyle, Laura, and Laura Winkiel. 2005. Geomodernisms: Race, Modernism, Modernity. Bloomington, IN: Indiana University Press.

Ellis, Havelock. 1922. The World of Dreams. Boston and New York: Houghton Mifflin Company.

Friedman, Susan Stanford. 2006. "Periodizing Modernism: Postcolonial Modernities and the Space/Time Borders of Modernist Studies.” Modernism/Modernity. 13.3: 425-443.

Gill, Claire. 2012. "Olive Schreiner, T. Fisher Unwin and the Rise of the Short Fiction Collection in Britain.” English Literature in Transition 1880-1920. 55.3: 315-338. 
David Leon Higdon. 1977. Time and English Fiction. London: Macmillan.

Jameson, Fredric. 1990. "Modernism and Imperialism.” In Nationalism, Colonialism and Literature, edited by Terry Eagleton, Fredric Jameson and Edward Said, 42-66. Minneapolis: University of Minnesota Press.

Jameson, Fredric. 1986. "Third-World Literature in the Era of Multinational Capitalism." Social Text 15: 65-88.

Joyce, James. 1973. A Portrait of the Artist as a Young Man. Harmondsworth: Penguin.

Lawrence, D.H. 1987. Women in Love. Cambridge: Cambridge University Press.

Lusty, Natalya and Helen Groth. 2013. Dreams and Modernity: A Cultural History. Abingdon and New York: Routledge.

McClintock, Anne. 1995. Imperial Leather: Race, Gender and Sexuality in a Colonial Context. London: Routledge.

Monsman, Gerald. 1991. Olive Schreiner's Fiction: Landscape and Power. New Brunswick, NJ: Rutgers University Press.

Murphy, Patricia. 2001. Time is of the Essence: Temporality, Gender and the New Woman. Albany, NY: State University of New York Press.

Nanni, Giordano. 2012. The Colonisation of Time Ritual, Routine and Resistance in the British Empire. Manchester: Manchester University Press.

Olive Schreiner Letters Online (accessed April 11, 2014). http://www.oliveschreiner.org

Patke, Rajeev S. 2013. Modernist Literature and Postcolonial Studies. Edinburgh: Edinburgh University Press.

Schreiner, Olive. 1894. Dreams. London: T. Fisher Unwin.

Schreiner, Olive. 1998. The Story of an African Farm. Oxford: Oxford University Press.

Schreiner, Olive. 1972. Undine. New York: Johnson Reprint Corporation. 
Snaith, Anna. 2014. Modernist Voyages: Colonial Women Writers in London, 1890-1945. Cambridge: Cambridge University Press.

Spillman, Deborah Shapple. 2012. British Colonial Realism in Africa: Inalienable Objects, Contested Domains. Basingstoke: Palgrave Macmillan.

Stanley, Liz. 2002. Imperialism, Labour and the New Woman: Olive Schreiner's Social Theory. Durham: Sociologypress.

Wollaeger, Mark, and Matt Eatough. 2012. The Oxford Handbook of Global Modernisms. New York: Oxford University Press.

Woods, Tim. 2010. "Modernism and African Literature." In The Oxford Handbook of Modernisms, edited by Peter Brooker, Andrzej Gasiorek, Deborah Longworth and Andrew Thacker. 926-941. Oxford: Oxford University Press.

Young, Robert J.C. 2001. Postcolonialism: An Historical Introduction. Oxford: Blackwell. 